\title{
COMPARISON OF NOUNS REDUPLICATION IN INDONESIAN AND JAPANESE LANGUAGE
}

\author{
Stephanus Mangga \\ University of Nanzan \\ E-mail: mangaa@ nanzan-u.ac.jp
}

APA Citation: Mangga, S. (2018). Comparison of nouns reduplication in Indonesian and Japanese language. English Review: Journal of English Education, 6(2), 19-26. doi: 10.25134/erjee.v6i2.1240.

Received: 28-02-2018

Accepted: $29-04-2018$

Published: 01-06-2018

\begin{abstract}
This article is a qualitative description of the nouns reduplication comparison in Indonesian and Japanese language. Nouns are restricted to the category on the noun which can be counted $(\mathrm{KBK})$. The data were taken from library source and analyzed by comparing the elements of similarity and difference. As result, it was found that there are similarities and differences between KBK's reduplication of Indonesian and Japanese language. The equations include three items, namely; a) it has simple type without affixes, b) it has complex type with changes of consonants, and c) it functions to declare the indefinite category of the group. While the differences consist of four items and they are not found in Japanese language. Those four items are: a) it is in the form of simply affix, b) it is in the complex form with the repetition of consonants, c) it functions to show group category indefinite, and d) it functions as types of category indefinite. Those differences prove that reduplication of $\mathrm{KBK}$ in Indonesian language are more productive that reduplication of $\mathrm{KBK}$ in Japanese language.
\end{abstract}

Keywords: reduplication, noun, Indonesian language, Japanese language

\section{INTRODUCTION}

Reduplication is one of linguistic reality which can be found in many languages. As Gómez and Voort state that "reduplication is a phenomenon that occurs in the majority of the world's languages...." (Gómez \& Voort, 2014, p. 1). Hence, reduplication between languages can be compared to see and find any differences and similarities. This is not only useful for documentation in the field of structural linguistics, but also practically useful for teaching and learning of both languages which are compared.

This study is a qualitative description of noun reduplication comparison of Indonesian and Japanese language. The somparison is made since it is assumed that there are similarities and differences in terms of function or type noun reduplication in both languages. For example, in reduplication of Japanese language, word 人 [hito] which means `person` becomes [hito-bito] 'people'. There is vowel change of $/ \mathrm{h} /$ become $/ \mathrm{b} /$ in the first syllable. The reduplicative word [hito-bito] can be categorized as reduplication with sound change. In Indonesian language, there is also reduplication with vowel change like lauk becomes lauk-pauk; sayur becomes sayurmayur. Those examples of reduplication in Indonesian and Japanese language functions to state "indefinite" meaning. It is called jamak in Indonesian language, while in Japanese language is called 複数 [fukusū]. However, according to Takayama (2012) and Ōsato (2013), there is few number of noun reduplication in Japanese language or it can be said that the amount of it is rare.

Based on the above introduction, there are three objectives to be achieved in this paper. First, it describes the similarities and differences of noun reduplication type in Indonesian and Japanese language. Second, it describes similarities and differences of noun reduplication function in Indonesian and Japanese language. Third, it explains why noun reduplication in Japanese is quite limited than in Indonesian language. 
In addition, this study will use size and function of reduplication theory proposed by Rubino (2005) to analyse the data. Rubino (2005) states that the systematic repetition within a word for semantic or grammatical purposes is known as reduplication. According to Rubino (2005), reduplication is divided into two major types those are full reduplication and partial reduplication. Full reduplication is reduplication from stem word. While partial reduplication appears in many form like in the form of double consonant or vowel lengthening. Moreover, based on the existence and inexistence of phoneme change and/or additional in reduplication, Rubino divided into simple reduplication and complex reduplication. Simple reduplication is reduplication without changes of particular phoneme. Complex reduplication is reduplication with changes of phonology materials like changes or additions vocal or consonant or the reversal of the phonemes order (Rubino, 2005). Moreover, the reduplication which relates to noun functions to describe number, distribution, indefinite, association, diminutive, and augmentative (Rubino, 2005).

\section{METHOD}

This study can be classified as descriptive qualitative. As stated by Flick (2009), qualitative research is of specific relevance to the study of social relations, due to the fact of the pluralisation of life worlds. Qualitative research can be done using written or spoken data. The data used in this study were library data. Those data were collected from several sources which discussed reduplication in Indonesian and Japanese language. They were
Takayama (2012), Ōsato (2013), Ferawati (2013), Simatupang (1983), Ramlan (2012), Yu (2015), Olson (2015), Kobayakawa (2004), Tamura (1991), Matsumoto (2009), Takayama (2013), and Ta (2014).

The data in this study were analyzed by using dividing technique. It means that the data will be divided to several parts (Sudaryanto, 2015). The first part was classifying the existence-inexistence of similarities and differences in type of reduplication. The second part was categorizing the existenceinexistence of similarities and differences in type of function. The last was explaining why noun reduplication in Japanese is quite limited than in Indonesian language.

In addition, there is data limitation in this study. It aims to get accurate analysis, so this study only discusses about noun reduplication. Moreover, the noun in this study was bounded into concrete and/or countable noun (KBK). KBK was chosen because the use of it in Indonesian language is more productive than in Japanese language.

\section{RESULTS AND DISCUSSION Types and functions of KBK reduplication in Japanese language}

There are two types of KBK reduplication in Japanese language which will be explained below.

\section{Simple reduplication}

Rubino (2005) said that simple reduplication means duplicating fixation phoneme. In other words, it is reduplication without sound changes. The simple reduplication can be seen in Table 1 below.

Table 1. Simple reduplication of KBK reduplication in Japanese language

\begin{tabular}{llll}
\hline \multicolumn{1}{c}{ Root word } & \multicolumn{1}{c}{ Gloss } & \multicolumn{1}{c}{ Reduplication } & \multicolumn{1}{c}{ Gloss } \\
\hline 家 [ie] & House & 家々 [ie-ie] & houses, housing \\
町 [machi] & City & 町々 [machi-machi] & cities, urban \\
村 [mura] & Village & 村々 [mura-mura] & villages, rural \\
山[yama] & Mountain & 山々 [yama-yama] & mountains, highland \\
道 [michi] & Street & 道々 [michi-michi] & streets, pathway \\
\hline
\end{tabular}

From the table, it can be seen that simple reduplication of KBK in Japanese language occurs in noun which cannot move and have the design of group. As a result, the function 
ENGLISH REVIEW: Journal of English Education Volume 6, Issue 2, June 2018

of reduplication shows indefinite of noun category of shüdan/dantai 'group.' It can be seen in examples below.

1) ie-ie gatachinarabu

house-RED. PS. in line stand

The houses is lined up stand.

(RED: Reduplication, PS: subject marker)

The reduplicative form of $i e-i e$ in example (1) shows that the number of house is more than one. However, it cannot be said as 'uncountable', but it is said as a group. In Indonesian language, it can be translated into word perumahan. The similar thing can be seen in example below.

2) arupusu no yama-yama ga mieru Alpes PM. mountain-RED. PS. visible 'Highland of Alpes is visible.'

(PM: possession marker)

The reduplicative form of yama-yama in example (2) shows that the number of mountain is indefinite. As a result, it can be expressed with highland (Alpes). Therefore, reduplicative of yama-yama shows that yama is more than one, but it shows 'a group of mountain.' It is similar to Olson's statement (2015), from Japanese people's statement that the reduplicative form of yama-yama means
p-ISSN 2301-7554, e-ISSN 2541-3643

https://journal.uniku.ac.id/index.php/ERJEE

"yama hitotsu janakute, sanmyaku no you na yama ga itsumo aru no arawasu kotoba." Those quote means `yama-yama words not only express existence of a mountain, but it shows a group of mountains.'

3) michi-michi ni hijō-sen ga harareru Pathway-RED. In emergency strip PS. installed

'Emergency strip is installed in pathway '.

The reduplicative form of michi-michi shows that the number of michi is more than one, but it cannot be classified as 'uncountable'. Consequently, form of michimichi functions to express 'group`. Those reduplications function to show indefinite meaning which means the number is more than one, but it creates a shüdan/dantai special 'group'.

\section{Complex reduplication}

Rubino (2005) said that complex reduplication is reduplication with some phonological changes like changes or addition of vocal or consonant or inversion of phoneme order. It can also be said as reduplication with sound changes (Verhaar, 2008). Table 2 below shows complex reduplication data of $\mathrm{KBK}$ in Japanese language.

Table 2. Noun complex reduplication in Japanese language

\begin{tabular}{llll}
\hline \multicolumn{1}{c}{ Root word } & \multicolumn{1}{c}{ Gloss } & \multicolumn{1}{c}{ Reduplication } & \multicolumn{1}{c}{ Gloss } \\
\hline 人 [hito] & person & 人々 [hito-bito] & people, a group of person \\
日 $[$ hi] & day & 日々 [hi-bi] & days, a group of day \\
神 [kami] & divinity & 神々 [kami-gami] & Divinity-deity \\
方 [kata] & master & 方々 [kata-gata] & masters, a group of master \\
国 [kuni] & country & 国々 [kuni-guni] & Countries \\
木 [ki] & tree & 木々 [ki-gi] & Tree, Trees \\
島 [sima] & island & 島々 [sima-zima] & islands, archipelago \\
品 [sina] & Item & 品々 [sina-zina] & items \\
\hline
\end{tabular}

Table 2 shows that KBK reduplication in Japanese marked with changes of root initial consonant. These changes happen in root initial consonant which have one or two syllables. Based on those changes, complex reduplication form of KBK in Japanese language is divided into three types. First, type $/ \mathrm{h} />/ \mathrm{b} /$. Root form of initial consonant $/ \mathrm{h} /$ will become /b/. It can be seen in reduplicative form of hito > hito-bito and hi > hi-bi. Second, type $/ \mathrm{k} />/ \mathrm{g} /$. Root form of initial consonant $/ \mathrm{k} /$ will become $/ \mathrm{g} /$. It can be seen in reduplicative form of kami > kami-gami dan kata > kata-gata. It is also happens in reduplication form of kuchi > kuchi-guchi, kuni > kuni-guni, ki > ki-gi, koe > koe-goe. 
Third, type /s/ > /z/. Root form of initial consonant /s/ will become /z/. It can be seen in reduplicative form of sima > sima-zima, sina > sina-zina, and sumi > sumi-zumi.

Similar to simple reduplication in Table 1 , complex reduplication group in Table 2 runs to show indefinite. Indefinite refers to 'uncertain' in number which can be 'many'. However, the meaning of 'many' is not associated with ‘uncountable` or 'infinite`, but it relates to 'grouping'. Grouping means the group number is more than one. Then, in Table 2 , it functions to show group indefinite of a dantai (group). It can be seen from the examples below.

\section{4) asoko de hito-bito ga tabeteiru}

there in people-RED. PS. eat

'People are eating over there.'

The reduplicative form of hito-bito explains about 'the existence of people's group`. Since it creates dantai 'group', so it can be said that there are many members of group. The expression may become different if people on that sentence is not in a group. It will become asoko de hito ga tabeteiru `Person is eating over there '.

5) watashi wa kami-gami wo shinjimasu

I PT. Divinity-RED. PO. believe

'I believe in divinity-deity'.

(PT: Topic marker, PO: Object marker)

The form of kami-gami explains 'group of divinity` and the group contains divinity and deity. Indefinite which is in the form of kamigami means divinity that is believed, and the number of it is more than one. The expression will be different if the belief is only one thing. It will become watashi wa kami wo shinjimasu 'I believe in God'.

Therefore, either simple or complex reduplication of KBK in Japanese language serves to declare indefinite in terms of the number of noun categories for group/collection. Thus, in Japanese language, the noun which is not categorized as groups/collections and/or it is not potentially forming groups/collections cannot be reduplicated. This is in accordance with what is said by Kobayakawa (2004) that in noun Japanese language which is not potentially form a group/collection is difficult to be reduplicated. As stated by Takayama (2012) and Olson (2015), reduplication of nouns in Japanese language does exist, but it is very limited in its use.

\section{Types and functions of KBK reduplication in Indonesian language \\ Simple reduplication}

$\mathrm{KBK}$ in Indonesia language is almost can be reduplicated as simply (total). In Indonesian language, basic noun or noun derivative with [+COUNT] can be reduplicated totally. Because all can be reduplicated completely, then there are much numbers of KBK reduplication in Indonesian language. The following table shows some simple reduplication of KBK in Indonesian language. The data which were given category I was basic nouns, whereas category II was noun derivative.

\begin{tabular}{|c|c|c|}
\hline Root & Category & reduplication \\
\hline orang & I & orang-orang \\
\hline sepeda & I & sepeda-sepeda \\
\hline mobil & I & mobil-mobil \\
\hline motor & I & motor-motor \\
\hline toko & I & toko-toko \\
\hline tokoh & I & tokoh-tokoh \\
\hline buku & I & buku-buku \\
\hline kursi & I & kursi-kursi \\
\hline meja & I & meja-meja \\
\hline gunung & I & gunung-gunung \\
\hline sawah & I & sawah-sawah \\
\hline jalan & I & jalan-jalan \\
\hline rumah & I & rumah-rumah \\
\hline pertempuran & II & pertempuran-pertempuran \\
\hline
\end{tabular}


ENGLISH REVIEW: Journal of English Education Volume 6, Issue 2, June 2018
p-ISSN 2301-7554, e-ISSN 2541-3643

https://journal.uniku.ac.id/index.php/ERJEE

\begin{tabular}{lll}
\hline pertemuan & II & pertemuan-pertemuan \\
perundingan & II & perundingan-perundingan \\
pengeluaran & II & pengeluaran-pengeluaran \\
pendapatan & II & pendapatan-pendapatan \\
makanan & II & makanan-makanan \\
minuman & II & minuman-minuman \\
\hline
\end{tabular}

The table shows that the simple reduplications of KBK in Indonesian language can be basic words without affixes (category I) and basic words with affixes (category II). Basic words with affixes of KBK are divided over three types. First, root morpheme + affix per-an. This can be seen in the form of pertempuran, pertemuan, and perundingan. Other forms which can be added into this type are pertikaian > pertikaian-pertikaian, perumahan > perumahan-perumahan, perkebunan > perkebunan-perkebunan, perusahaan > perusahaan-perusahaan, perbaikan > perbaikan-perbaikan, and others. Second, root morpheme + affix $p e(N)$-an. This can be seen in the form of pengeluaran and pendapatan. Other forms which is similar to this type is penyamaran > penyamaranpenyamaran, pemotongan > pemotonganpemotongan, pemalsuan > pemalsuanpemalsuan, pengerusakan > pengerusakanpengerusakan, and others. Third, root morpheme + affix $-a n$. This can be seen in the form of makanan and minuman. Other forms which are similar to this type are pakaian > pakaian-pakaian, tumbuhan > tumbuhantumbuhan, lukisan > lukisan-lukisan, manisan $>$ manisan-manisan, and others.

The use of KBK reduplications such as those on Table 3 functions to declare indefinite in terms of numbers. According to Simatupang (1983), reduplication with nouns as basically serves to proclaim 'plurality' referent of related noun. It is a bit different with that term, Ramlan (2012) stated that one of the meanings of the process of repetition (noun) was declared the meaning 'many'. In this paper 'plurality' and 'many' are melted into the term offered by Rubino (2005) that is 'indefinite'.

Based on the table 3 above, the indefinite can be distinguished into two categories, those are category of groups and category of types/kinds. Consequently, it can be said that simple reduplication of KBK in Indonesia language serves to proclaim: a) group category indefinite, and b) types/kinds category indefinite. Function of group category indefinite is found in the form of KBK reduplicative which is given category I. Meanwhile, the functions of types/kinds category indefinite are found in the form of KBK reduplicative which is given category II. The following examples may be able to clarify the Division.

6) a. Pak Tono sedang mengumpulkan sepeda-sepeda bekas di gudang.

b. Pak Tono sedang mengumpulkan sepeda-sepeda di gudang.

7) a. Ibu sedang menghitung pengeluranpengeluaran bulan lalu

b. Ibu sedang menghitung pengeluaranpengeluaran

The reduplicative form of sepedasepeda in the example (6a) above stated groups of sepeda with its speciality is bekas (older). Even if such specificity is removed, the reduplicative form of sepeda-sepeda still shows group category indefinite as stated in the example (6b). Meanwhile, the reduplicative form of pengeluaranpengeluaran in the example (7a) declares the types or kinds of pengeluaran with its specificity in time that is bulan lalu. Even if such specificity is omitted, the form of pengeluaran-pengeluaran still declares the types or kinds as stated in the example (7b).

\section{Complex reduplication}

Complex reduplication of KBK in Indonesian language is distinguished into three types; 1) Type A - KBK reduplication with changes of consonant, 2) Type B - KBK reduplication with repetition of consonant, and 3) Type $\mathrm{C}-$ KBK reduplication with affix $-a n$. The following table shows the detail of them. 
Comparison of nouns reduplication in Indonesian and Japanese language

Table 4. Complex reduplication of KBK in Indonesian language

\begin{tabular}{ccc}
\hline root & reduplication & type \\
\hline Sayur & sayur-mayur & $\mathrm{A}$ \\
Laki & lelaki & $\mathrm{B}$ \\
mobil & mobil-mobilan & $\mathrm{C}$ \\
\hline
\end{tabular}

Table 4 shows that the form of sayurmayur establishes type A. It is marked by the changes of consonant $/ \mathrm{s} /$ becomes $/ \mathrm{m} /$. The changes of consonant occur at the initial consonant. It includes the same type like lauk $>$ lauk-pauk. In the form of lauk-pauk, the changes is consonant /// becomes /p/. Type B is represented by form of lelaki. The changes of consonant occur at the initial consonant and the addition of vocal/e/. It can be formulated with RED. K/e/ + morfem dasar (K= consonant). Words reduplication included into this type are tamu > tetamu. Another forms which can also be grouped into this type are jari > jemari, tali > temali, daun > dedaunan, and pohon > pepohonan. Type $\mathrm{C}$ is represented by form mobil > mobil-mobilan. There is repetition with affix - an. It can be formulated with RED. Root morpheme + affix $-a n$. Words reduplication included into this type are kereta > kereta-keretaan, orang > orang-orangan, kera > kera-keraan, gunung $>$ gunungan, and others.

Function of types A and B are the same that is stating indefinite. Nevertheless, the remains can be distinguished over; a) indefinite of type/category for type A, and b) group category indefinite for type B. whereas type $\mathrm{C}$ serves to reveal similarities with what is referred to in the basic form. As result, it can be said that the complex reduplication of $\mathrm{KBK}$ in Indonesian language has several functions in accordance with the type of the reduplicative form.

\section{Comparison of KBK reduplication in Indonesian and Japanese language}

Based on the above description, it can be seen that the KBK reduplication in Indonesian and Japanese language have similarities and differences. The similarities are: a) both languages have KBK reduplicative of simple and complex type, and b) both languages have function that stated indefinite (not singular, plural). Then the difference are: a) there is no affix KBK reduplication in Japanese language as in Indonesian language, b) there is no KBK reduplication with repetition of consonant in Japanese language as in Indonesia, and c) in Japanese language, KBK reduplication only serves to state group category indefinite, whereas in Indonesian language of Indonesia, it is not only states group category indefinite but also it states types category indefinite. The following table shows those similarities and differences.

Table 5. The similarities and differences of KBK reduplication of Indonesian and Japanese

\begin{tabular}{clcc}
\multicolumn{4}{c}{ language } \\
\hline No & \multicolumn{1}{c}{ Item } & Indonesian Language & Japanese Language \\
\hline $\mathbf{1}$ & Simple non-affix & + & + \\
$\mathbf{2}$ & Simple with-affix & + & - \\
$\mathbf{3}$ & Complex with consonant changes & + & + \\
$\mathbf{4}$ & Complex with consonant repetition & + & - \\
$\mathbf{5}$ & Complex with-affix & + & - \\
$\mathbf{6}$ & Group category indefinite & + & + \\
$\mathbf{7}$ & Types category indefinite & + & - \\
\hline
\end{tabular}

Based on the table, it can be said that the use of language in Indonesia KBK reduplication is more productive than in Japanese language. What proves it, on Indonesian language column, all items is positive (+), whereas Japanese language only has three positive (+). This was reinforced by a statement of Matsumoto (2009) that though Japanese language has a form of nouns reduplication, however the scope of its use is very limited. The reduplicative form of 'many' in Japanese language is not as productive as the use of the form reduplicative in Indonesian language, because Japanese language has its 
ENGLISH REVIEW: Journal of English Education Volume 6, Issue 2, June 2018

own system to declare the meaning of 'many' or 'plural' or 'single'. There are two ways to produce 'many' in Japanese language those are: a) noun + tachi and b) sorera no + noun.

The first formulation, nomina + tachi is usually used for the noun category 'animate' (living things). The word tachi is 'plural' maker which is specific to the lifeless beings (Yu, 2015). Consequently, in Japanese language, there is expression hito tachi 'people' (group of people), inu tachi 'dogs' (group of dogs), neko tachi 'cats' (Group of cats), hana tachi 'flowers' (group of flowers). As a result, KBK Japanese language reduplication is not as productive as in Indonesian language because Japanese language has formulation noun + tachi which is to declare the category indefinite of group.

The second formulation, sorera no + noun is used for all animate the lifeless adjective. The word sorera is actually the plural form of the word sore which means 'that'. While for 'this' is used the word kore, with the plural form is korera. For example, hito 'person' > sorera no hito 'that people', korera no hito 'these people'; or hon 'book' > sorera no hon 'that books', korera no hon 'this books'. Hence, in Japanese language, KBK reduplication is not as productive as in Indonesian language because Japanese language has formulations sorera no + noun atau korera no + noun to indicate category indefinite of types/kinds.

\section{CONCLUSION}

Indonesian and Japanese language has the KBK reduplication form. The equation encompasses three items namely a) simple type without affixes, b) complex type with changes of consonants, and c) function to declare the category indefinite of the group. The difference is in the four items, namely a) Indonesian language has affix simple form while Japanese language does not have it; $b$ ) Japanese language does not have the form of complex with the repetition of consonants whereas Indonesian language have it; c) Indonesian language have affix complex form whereas Japanese language does not have it; and d) Japanese language only have group category indefinite whereas Indonesia
p-ISSN 2301-7554, e-ISSN 2541-3643

https://journal.uniku.ac.id/index.php/ERJEE

language have it and have function of category indefinite of types/categories. Finally, it can be said that KBK reduplication in Japanese language is not as productive as in Indonesian language. However, it does not mean that Japanese language have 'less' expression to declare the meaning of 'plural' or 'singular', because it has another expression those are noun + tachi dan sorera no + noun (korera no + noun).

\section{ACKNOWLEDGMENTS}

This work was generously supported by a research grant from Nanzan University Pache Research Subsidy I-A-2 for the 2017 academic year.

\section{REFERENCES}

Ferawati, L. (2013). Analisis kontrastif reduplikasi bahasa Indonesia dan bahasa Jepang. Unpublished thesis, Universitas Brawijaya.

Flick, U. (2010). An introduction to qualitative research. London: Sage Publication Inc.

Kobayakawa. (2004). Nihongo no fukusū hyōgen. Mind and Language, 3, 35-50.

Matsumoto, J. (2009). Nihongo ni okeru jōgo fukusūgata no seisei kanōsei ni tsuite. Bulletin of Toyo Gakuen University, 17, 243-249. Tokyo: Universitas Toyo Gakuen.

Olson, L. (2015). Form and function of reduplicated nouns in Japanese. Unpublished Thesis, Universitas Stockholms.

Ōsato, A. (2013). Jōgo no kenkyū. Studies in Language and Culture, XXII(22), 1-16.

Ramlan, M. (2012). Morfologi suatu tinjauan deskriptif. Yogyakarta: CV Karyono.

Rubino, C. (2005). Reduplication: Form, function and distribution (pp. 11-29). In B. Hurch (Ed.), Studies on reduplication. Berlin: Walter de Gruyter.

Simatupang, M. D. S. (1983). Reduplikasi morfemis bahasa Indonesia. Jakarta: Djambatan.

Sudaryanto. (2015). Metode dan aneka teknik analisis bahasa: Pengantar penelitian wahana

kebudayaan secara linguis. Yogyakarta: Duta Wacana University Press.

Ta, U. (2014). Gendaigo jōgo, jōgo keiyōshi no kōzō ni tsuite: Gendai chūgokugo, nihongo no jōgo, jōgo keiyōshi. Journal of higher education, 11, 76-87.

Takayama, R. (2013). Nihongo sho hōgen no shi mōra jōgo o hikaku suru kokoromi" (An Attempt at Cross-dialectal Comparison of 4-Mora Reduplicated Words in Japanese Dialects). Departmental Bulletin Paper, 34, 143 - 183. Tokyo: Universitas Tokyo.

Tamura, Y. (1991). Gendai nihongo ni okeru jōgo ni tsuite: Sū gainen kara mita jōgo. Bulletin of the International Student Center, I, 41-47. Universitas Hiroshima. 


\section{Stephanus Mangga}

Comparison of nouns reduplication in Indonesian and Japanese language

Verhaar, J. W. M. (2008). Asas-asas linguistik umum.

Yogyakarta: Gadjah Mada University Press.
Yu, K. (2015). Jōgo no sho kinō. Departmental Bulletin Paper, XXIV, 25-27. Universitas Gakushuin. 